\title{
"Exploring the critical factors that hinder the growth of incubatees in South Africa"
}

\begin{tabular}{ll} 
& Thobekani Lose iD https://orcid.org/0000-0001-6696-4468 \\
AUTHORS & Robertson K. Tengeh \\
Eugine Tafadzwa Maziriri & Nkosivile Welcome Madinga iD https://orcid.org/0000-0003-4026-7423 \\
& Thobekani Lose, Robertson K. Tengeh, Eugine Tafadzwa Maziriri and Nkosivile \\
& $\begin{array}{l}\text { Welcome Madinga (2016). Exploring the critical factors that hinder the growth of } \\
\text { incubatees in South Africa. Problems and Perspectives in Management, 14(3-3), } \\
\text { 698-704. doi:10.21511/ppm.14(3-3).2016.13 }\end{array}$ \\
ARTICLE INFO & http://dx.doi.org/10.21511/ppm.14(3-3).2016.13 \\
\hline DOI & Thursday, 10 November 2016 \\
\hline RELEASED ON & "Problems and Perspectives in Management" \\
\hline JOURNAL & LLC “Consulting Publishing Company "Business Perspectives" \\
\hline FOUNDER &
\end{tabular}

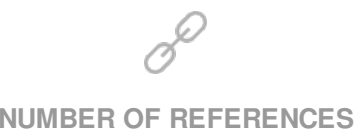

0

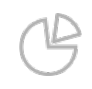

NUMBER OF FIGURES

0

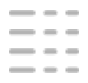

NUMBER OF TABLES

0

(C) The author(s) 2022. This publication is an open access article. 


\title{
Thobakani Lose (South Africa), Robertson K. Tengeh (South Africa), Eugine Tafadzwa Maziriri (South Africa), Nkosivile Welcome Madinga (South Africa) \\ Exploring the critical factors that hinder the growth of incubatees in South Africa
}

\begin{abstract}
In as much as entrepreneurial action fosters job creation and economic growth, entrepreneurs encounter the significant risk of failure, and community bears the brunt. Though business incubators were designed to provide support and hope to ailing businesses, evidence suggests that not all on these programs succeed. Going on the assumption that even businesses on incubation programs do not seem to be immune to failure, this study sought to determine the key factors that hinder the growth of incubatees in South Africa.
\end{abstract}

Adopting a quantitative approach, the questionnaire was utilized as the primary data collection tool, and the snowball sampling method was employed resulting in a sample size of 93 respondents. The research participants for this study were limited to firms that were registered on the databases of two business incubators who promote small business development strategy and programs in Cape Town and Johannesburg, respectively. The findings indicated that lack of funding, lack of credit facility, competition, crime, lack of access to external market, lack of business skills and lack of product selection and design were the key factors that hinder the growth of incubatees.

Given the substantial resources invested in business incubation programs, the fact that business incubators are entrepreneurial ventures in themselves, understanding and finding sustainable solutions to the factors that hinder the growth of their clients (incubatees) would be a win-win solution for the relevant stakeholders.

Keywords: business incubatees, business incubators, entrepreneurship, growth, South Africa.

JEL Classification: M1, L84.

\section{Introduction}

Globally, the move to acknowledge the role of Small and medium-sized enterprises (SMEs) with regards to economic development has gained traction over the years. Of particular concern has been the eminent contribution of that a flourishing SMEs sector. As such, it is believed by many that SMEs are very significant in terms of economic growth, job creation, and poverty reduction (Lose, Maziriri and Madinga, 2016; Choto, Tengeh and Iwu, 2014).

Despite the contribution made by SMEs to grow the economy, their failure rate in South Africa remains high (Willemse, 2010; Olawala \& Garwe, 2010; Worku, 2015; Choto, 2015; Lose, 2016). The start-up and early growth of new businesses has been found to be partly dependent on both factors within and beyond the entrepreneur's nexus of control. In view of the pressing need to keep the failure of SMEs under control, researchers, industry experts, many government officials believed it is necessary to improve start-up enterprises their survival and growth (SEDA, 2016). One of the strategic tools perceived to

(C) Thobakani Lose, Robertson K. Tengeh, Eugine Tafadzwa Maziriri, Nkosivile Welcome Madinga, 2016.

Thobakani Lose, Ph.D. Student, Department of Logistics, Faculty of Management sciences, Vaal University of Technology, South Africa.

Robertson K. Tengeh, Ph.D., Senior Lecturer, Faculty of Business \&

Management Sciences, Cape Peninsula University of Technology, South Africa.

Eugine Tafadzwa Maziriri, Faculty of Management Sciences, Vaal University of Technology, South Africa.

Nkosivile Welcome Madinga, Lecturer, Department of Integrated Marketing Communications, Faculty of Marketing Management, AAA School of Advertising, Cape Town, South Africa. be crucial to the start-up and survival of SMEs has been business incubators (BIs). BIs play the critical role of aiding ailing businesses by providing a wide range of services such as: office equipment; computer equipment/services; business plan and product development; affordable space/building facility training/coaching; legal counseling/intellectual property; property; business networking and so on. Though BIs are designed to provide critical support to ailing business, there is considerable evidence to suggest that the challenges of incubatees persist even while on these programs.

Although business incubation as a research area has gained traction over the years, the relevance of investigating the critical factors that hinder the growth of business incubatees in South Africa remains glaring. This is particularly so, because previous studies in South Africa have marginally engaged incubators or incubatees along these lines. For instance, those that focused on the impact and performance of business incubators include: Kavhumbura (2014), Masutha and Rogerson (2014), Diedericks (2015) and Ntlamelle (2015). Focusing on incubator service and sustainability have been Cullen, Calitz and Chandler (2014), Dubihlela and Van Schaikwyk (2014). A close parallel has been that of Lose and Tengeh (2015) that looked at the challenges of business incubators in the Western Cape.

Exploring the challenges of incubatees has been limited to Choto and Tengeh (2014) whose focus was on survivalist entrepreneurs in the Cape Metropolitan 
area and the challenges that they had prior to joining the incubation programs. Geared to be complementary, the current study is focused on the challenges that incubatees' encounter while still on incubation program. Beyond this, the previous study was expanded to another province (Gauteng).

\section{Literature review}

1.1. Business incubators and incubateees. The concept of business incubation refers to the framework designed to nurture and provide support to young and struggling firms during turbulent times. Given the relevance of this support mechanism today, many governments and the private sector have become actively involved and the firms that provide such support are referred to as business incubators. Accordingly, business incubatees are entrepreneurs who partake in the incubation programs, with the aim of developing or growing their enterprises.

Business incubators are perceived to foster the creation of new firms and supporting existing ones (Bergek \& Norrman, 2008; Lose \& Tengeh, 2015) by providing incubatees with a supportive environment, nurturing and developing them during the start-up phase (Ndabeni, 2008; Cullen, Calitz \& Chandler, 2014; Chirambo, 2014; Albort-Morant \& Ribeiro-Soriano, 2016). Incubatees, through the creation of employment and poverty reduction, are considered as a key factor in economic development. Thus, encouraging entrepreneurship activities contribute to the GDP, new product development, new enterprise development, new market and equitable distribution of income (Diedericks, 2015; Choto, 2015).

1.2. Business growth and incubatees. Delmar and Wiklund (2008) concur that there is no universally accepted method of measuring business growth given the inconsistency in the definition of the concept. Generally, the term "business growth" is used to refer to various things, such as an increase in total sales volume, increase in production capacity, increase in employment, increase in production volume, increase in the use of raw material and power (Yeboah, 2015). Business growth is typically defined and measured, using absolute or relative changes in sales, assets, employment, productivity, profits and profit margins (Koech, 2011; Olawale \& Garwe, 2010). Given that sales data are usually readily available and business owners themselves attach high importance to sales as an indicator of business performance.

Growth has been used as a simple measure of success in business and has also been suggested as the most appropriate indicator of the performance for surviving small firms (Walobwa, Ngugi \& Chepkulei, 2013). Keil $(2009$, p. 31) states that every business wants to grow and that to grow, a business must maintain longterm survival, and the owner/manager must be able to identify and remove obstacles.
1.3. The critical factors that affect the growth of incubatees. Incubatee growth is characterized not limited to financial growth, market expansion, product development, organizational growth, product quality and uniqueness. However, incubatees still confronted with many factors that affect their development, while in the incubation program. This includes the factors to be discussed in the following sections.

1.3.1. Lack of funding. The lack of raising capital is a key challenge to the growth of incubatees. Asoba and Tengeh (2016) concur that obtaining cash flow is crucial in getting necessary equipment, skilled labor and property to run the business effectively. Hence, business incubatees are mainly supported by business incubators during the start-up phase.

1.3.2. Incubator administration. Worldwide, business incubators are credited for providing affordable space, premises and much more to incubatees (Diedericks, 2015; Lose et al., 2016). Yet, the time that an incubatee spends on the program impacts on its propensity to grow. A mobile incubator could be the logical solution to reaching many of the incubatees in need.

1.3.3. Lack of credit facility. Since incubatees are operating in the incubation program, they lack tangible resources to obtain funding from the banks. In the same view, Asoba \& Tengeh (2016) mentioned that commercial banks are reluctant to provide loans to emerging businesses, particularly to someone who does not have an income, credit history and collateral security.

1.3.4. Lack of support from the incubator. There is considerable evidence to suggest business incubatees do not get value for their money. From a skills perspective, it is argued that the dismal support received by incubatees can be ascribed to lack of business-related skills on the part of the incubator and this stems from the fact most of their management team come from an entrepreneurial (Buys \& Mbewana, 2007; Tengeh \& Choto, 2015).

1.3.5. Competition. Competition is a plausible challenge that an entrepreneur faces when starting a business (Kanchana, Divya \& Beegom, 2013). Facilitated by information technology, the world has become a global village and this has made competition an imminent threat to the growth of incubatees even on the domestic front. Justino and Tengeh (2016) are of the view that small enterprises lack strategic approach to overcome competition in the market.

1.3.6. Crime. In South Africa, crime and corruption remains high and sometimes translates into the increased expenditure that prevents the growth of businesses (including those on incubation programs). It is believed that small organizations suffer the most from burglary, theft, robbery and shoplifting (Justino 
$\&$ Tengeh, 2016). Some may argue that crime makes South Africa one of the most unfavorable countries to do business in (Justino \& Tengeh, 2016; Lose, 2016).

1.3.7. Lack of business skills. Incubatees lack necessary business skills in order to reach the business goals and to be able to gain market share. A study conducted by Lose (2016) suggests that incubatees should continue to participate in the incubation program to obtain relevant skills such as financial management, technical, personal and business management skills to enhance its daily operations.

1.3.8. Lack of documentation. The lack of documents by business incubatees affects the growth of incubatees. This pertains to documents such as section relates to tax relevance certificate, proof of company registration, business plan and identify document. It has been observed that the majority of business banks take into consideration these documents in their evaluation of applications for funding (Pretorius \& Shaw, 2004).

1.3.9. Lack of access to technology. Okpara (2011) asserts that limited access to technology hinders the growth of entrepreneurs. To bridge this technology gap, it is recommended that essential for business incubators are to own an advanced technological facility.

\section{Research methodology}

Vijayalakshmi and Sivapragasam (2008) are of the view that two methods can be followed when conducting research, namely, qualitative and quantitative research. Pooe, Mafini and Makhubele (2015) point out that qualitative research involves the collection, analysis, and interpretation of data that are not reduced to numbers easily. On the other hand, Sheldon (2015) is of the view that the quantitative research approach pays particular attention to the objective measurement and the statistical, mathematical, or numerical analysis of the collected data by making use of polls, questionnaires, and surveys, or by controlling pre-existing statistical data using computational techniques. The researchers opted for a quantitative research approach for this study, because it enhances the accuracy of results through statistics analysis (Berndt \& Petzer, 2011) and avoids the elements of subjectivity associated with the qualitative approach (Du Plessis \& Rosseau, 2007).

2.1. Target population. A target population is the complete unit from which a sample is chosen (Bryman \& Bell, 2011), sharing similar characteristics relevant for the purpose of the research (Kent, 2007). It also includes the restrictions of barring individuals to form part of the population (Clow \& James, 2014). The target population for this study was restricted to all small business enterprises operating in the Western Cape Province and Gauteng Province of South Africa that were on the incubation programs and in the databases of two identified organizations in both sites. These are business incubators promote small business development strategy and programs in Cape Town and Johannesburg, South Africa during the course of the investigation.

2.2. Sample size. A sample can be defined as a portion of a larger population (Dube, Roberts-Lombard \& Van Tonder, 2015, p. 243). Roets (2013, p. 36) defines sample size as the count of factors involved in the study. According to Choto and Tengeh (2014), a sample size larger than 30 and less than 500 is appropriate for most research studies. This research study utilized 93 participants. In order to arrive at a sample size of 93 , whereby with 35 participants where from Johannesburg, Braamfontein, and 58 participants where from Cape Town, Cape Metropolitan area. The Raosoft sample calculator was also utilized to arrive at a sample of 93 with a confidence level of $100 \%$. Thus, the study utilized 93 participants made up of 35 from Braamfontein in Johannesburg, and 58 from, the Cape Metropolitan area, in Cape Town.

2.3. Sampling technique. Dahlberg and McCaig (2010) point to probability and non-probability sampling as the two major sampling methods. As nonprobability sampling method, snowballing was utilized for this study. It entails that the researcher recruits the primary participant, who, in turn, recommends another (Choto \& Tengeh, 2014). The snowball sampling method was reckoned to be the most appropriate method for this study, as the researchers had earmarked a few key informants to begin the recruitment process with.

2.4. Data analysis. All the measurement items were measured by a five-point Likert scale, whereby $1=$ strongly disagree, $2=$ disagree, $3=$ neither disagree nor agree/neutral, $4=$ agree and $5=$ strongly agree. All the 93 questionnaires returned were processed for analysis. Seven questionnaires were deemed not usable due to physical damage or being incomplete. The Statistical Package for Social Sciences (SPSS) software to statistically analyze the primary data, and descriptive statistics was the main concern. According to Denscombe (2007), descriptive statistics allows the researcher to critically analyze the results, examine the interconnection of data and provide a meaningful conclusion. Hence, the SPSS provided the platform for the presentation of the results in the form of figures, graphs, and frequencies and percentages (Coldwell \& Herbst, 2004).

\section{Presentation and discussions of findings}

In this section, the results are presented, analyzed and interpreted in relation to the research objective.

3.1. Lack of funding. Table 1 indicates that a total of $56(60 \%)$ respondents strongly agree that a lack of funding was a critical factor that hinders the growth of 
incubatees, followed by 31 (33\%) respondents agreed, while some $3(3 \%)$ said they were neutral with the statement. It is, thus, revealed that business incubatees in the Western Cape Province and Gauteng Province of South Africa experience some hardships in obtaining funding. This is in line with Chinomona and Maziriri (2015) findings that access to start-up capital is a major stumbling block to venturing in a new business. In addition, the results of this study are also in line with literature. Lose and Tengeh (2016), as well as Fatoki and Chindoga (2011, p. 163) point out that lack of finance is one of the major constraints to the formation of new enterprises and entrepreneurs need to access to both internal and external finance in order to grow. Masutha and Rogerson's (2014) study revealed that none of entrepreneurs revived any funding from the business incubator.

Table 1. Getting funding is a challenge to growing my business

\begin{tabular}{|c|c|c|c|c|c|}
\hline \multicolumn{2}{|c|}{} & Frequency & Percent & $\begin{array}{c}\text { Valid } \\
\text { percent }\end{array}$ & $\begin{array}{c}\text { Cumulative } \\
\text { percent }\end{array}$ \\
\hline \multirow{4}{*}{ Valid } & 1 & 1 & 1.1 & 1.1 & 1.1 \\
\cline { 2 - 6 } & 2 & 2 & 2.2 & 2.2 & 3.2 \\
\cline { 2 - 6 } & 3 & 3 & 3.2 & 3.2 & 6.5 \\
\cline { 2 - 6 } & 4 & 31 & 33.3 & 33.3 & 39.8 \\
\cline { 2 - 6 } & 5 & 56 & 60.2 & 60.2 & 100.0 \\
\cline { 2 - 6 } & Total & 93 & 100.0 & 100.0 & \\
\hline
\end{tabular}

Table 2. Incubator administration is costly and timeconsuming

\begin{tabular}{|c|c|c|c|c|c|}
\hline \multicolumn{2}{|c|}{} & Frequency & Percent & Valid percent & Cumulative percent \\
\hline \multirow{4}{*}{ Valid } & 1 & 14 & 15.1 & 15.1 & 15.1 \\
\cline { 2 - 6 } & 2 & 36 & 38.7 & 38.7 & 53.8 \\
\cline { 2 - 6 } & 3 & 28 & 30.1 & 30.1 & 83.9 \\
\cline { 2 - 6 } & 4 & 14 & 15.1 & 15.1 & 98.9 \\
\cline { 2 - 6 } & 5 & 1 & 1.1 & 1.1 & 100.0 \\
\cline { 2 - 6 } & Total & 93 & 100.0 & 100.0 & \\
\hline
\end{tabular}

Table 2 reports on the cost of administering an incubator. Interestingly, the respondents who agreed to the statement made up twenty-five $14(15 \%)$ percent of the participants that the incubator administration is costly and time-consuming. The respondents who were neutral with the incubator administration is costly and time-consuming represented $28(30 \%)$ and 36 (39\%) of the participants disagreed. Only $1 \%$ of the respondents in this research strongly agreed that incubator administration is costly and time-consuming.

Table 3. Lack of credit facility is a challenge to the growth of my business

\begin{tabular}{|c|c|c|c|c|c|}
\hline \multicolumn{2}{|c|}{} & Frequency & Percent & Valid percent & Cumulative percent \\
\hline \multirow{4}{*}{ Valid } & 1 & 9 & 9.7 & 9.7 & 9.7 \\
\cline { 2 - 6 } & 2 & 7 & 7.5 & 7.5 & 17.2 \\
\cline { 2 - 6 } & 3 & 18 & 19.4 & 19.4 & 36.6 \\
\cline { 2 - 6 } & 4 & 39 & 41.9 & 41.9 & 78.5 \\
\cline { 2 - 6 } & 5 & 20 & 21.5 & 21.5 & 100.0 \\
\cline { 2 - 6 } & Total & 93 & 100.0 & 100.0 & \\
\hline
\end{tabular}

Table 3 sought responses regarding the extent to which incubatees agreed that lack of credit facility is a challenge to the growth of their business. The majority 39 (42\%) of respondents stated that they agree that the limited credit facility affect their growth. The next high frequency 20 (22\%) was for strongly agree. Incubatees are operating in the incubator facility and they lack collateral security to access more resources.

Table 4. Inability to communicate effectively with incubation managers is a challenge to growth

\begin{tabular}{|c|c|c|c|c|c|}
\hline \multicolumn{2}{|c|}{} & Frequency & Percent & $\begin{array}{c}\text { Valid } \\
\text { percent }\end{array}$ & $\begin{array}{c}\text { Cumulative } \\
\text { percent }\end{array}$ \\
\hline \multirow{5}{*}{ Valid } & 1 & 11 & 11.8 & 11.8 & 11.8 \\
\cline { 2 - 6 } & 2 & 18 & 19.4 & 19.4 & 31.2 \\
\cline { 2 - 6 } & 3 & 31 & 33.3 & 33.3 & 64.5 \\
\cline { 2 - 6 } & 4 & 20 & 21.5 & 21.5 & 86.0 \\
\cline { 2 - 6 } & 5 & 13 & 14.0 & 14.0 & 100.0 \\
\cline { 2 - 6 } & Total & 93 & 100.0 & 100.0 & \\
\hline
\end{tabular}

Table 4 shows that $11(12 \%)$ of the respondents said strongly disagree; 18 (19\%) replied disagree; $31(33 \%)$ said they were neutral; $20(22 \%)$ agreed and $13(14 \%)$ answered strongly agree. These results are in consistence with the works of Masutha and Rogerson (2014) who emphasized that "most entrepreneurs complained about what seems to be a breakdown in communication between incubator management and their incubatees. Entrepreneurs were also concerned by business development practitioners who do not seem to have their interest at heart".

Table 5. I experience lack of support from the incubator and local government

\begin{tabular}{|c|c|c|c|c|c|}
\hline \multicolumn{2}{|c|}{} & Frequency & Percent & $\begin{array}{c}\text { Valid } \\
\text { percent }\end{array}$ & $\begin{array}{c}\text { Cumulative } \\
\text { percent }\end{array}$ \\
\hline \multirow{4}{*}{ Valid } & 1 & 21 & 22.6 & 22.6 & 22.6 \\
\cline { 2 - 6 } & 2 & 28 & 30.1 & 30.1 & 52.7 \\
\cline { 2 - 6 } & 3 & 29 & 31.2 & 31.2 & 83.9 \\
\cline { 2 - 6 } & 4 & 11 & 11.8 & 11.8 & 95.7 \\
\cline { 2 - 6 } & 5 & 4 & 4.3 & 4.3 & 100.0 \\
\cline { 2 - 6 } & Total & 93 & 100.0 & 100.0 & \\
\hline
\end{tabular}

Table 5 show that $21(23 \%)$ of the respondents said strongly disagree; 28 (30\%) replied disagree; $29(31 \%)$ said they were neutral; $11(12 \%)$ agreed and $4(4 \%)$ answered strongly agree. The findings of this study are in contrast with the previous researchers such as Ekeledo and Bewayo (2009) who pointed out that small business assistance from governments of African countries is weak and inadequate. Wallace (1999) also confirms that small business assistance from governments of African countries is weak and inadequate. 
Table 6. Competition is a constraint to growth

\begin{tabular}{|c|c|c|c|c|c|}
\hline \multicolumn{2}{|c|}{} & Frequency & Percent & Valid percent & Cumulative percent \\
\hline \multirow{4}{*}{ Valid } & 1 & 6 & 6.5 & 6.5 & 6.5 \\
\cline { 2 - 6 } & 2 & 8 & 8.6 & 8.6 & 15.1 \\
\cline { 2 - 6 } & 3 & 32 & 34.4 & 34.4 & 49.5 \\
\cline { 2 - 6 } & 4 & 33 & 35.5 & 35.5 & 84.9 \\
\cline { 2 - 6 } & 5 & 14 & 15.1 & 15.1 & 100.0 \\
\cline { 2 - 6 } & Total & 93 & 100.0 & 100.0 & \\
\hline
\end{tabular}

Table 6 required respondents to indicate the extent to which they agreed that competition is a constraint to growth in the business. The majority of the respondents 33 (36\%) felt that competition is a constraint in order to develop their enterprises. The next highest number of respondents simply disagree $32 \quad(34 \%)$ that competition is a constraint. Fatoki (2014) elucidates that entrepreneurs need resources such as fixed assets and working capital to be able to achieve a competitive advantage in the market.

Table 7. Crime is a challenge to growth

\begin{tabular}{|c|c|c|c|c|c|}
\hline \multicolumn{2}{|c|}{} & Frequency & Percent & Valid percent & Cumulative percent \\
\hline \multirow{6}{*}{ Valid } & 1 & 3 & 3.2 & 3.2 & 3.2 \\
\cline { 2 - 6 } & 2 & 2 & 2.2 & 2.2 & 5.4 \\
\cline { 2 - 6 } & 3 & 19 & 20.4 & 20.4 & 25.8 \\
\cline { 2 - 6 } & 4 & 44 & 47.3 & 47.3 & 73.1 \\
\cline { 2 - 6 } & 5 & 25 & 26.9 & 26.9 & 100.0 \\
\cline { 2 - 6 } & Total & 93 & 100.0 & 100.0 & \\
\hline
\end{tabular}

Table 7 required incubates to assess their degree of agreement in terms of whether the crime is a challenge to grow their business. The highest number of respondents $44(47 \%)$ agreed that crime affect their growth. While the next high percentage frequency $25(27 \%)$ was observed for those who strongly agree. This corresponds to the finding of Worku (2015) which proves that accessing capital is still a restriction to grow small enterprises.

Table 8. The seasonal and irregular nature of trade make it difficult to forecast growth

\begin{tabular}{|c|c|c|c|c|c|}
\hline \multicolumn{2}{|c|}{} & Frequency & Percent & Valid percent & Cumulative percent \\
\hline \multirow{4}{*}{ Valid } & 1 & 5 & 5.4 & 5.4 & 5.4 \\
\cline { 2 - 6 } & 2 & 7 & 7.5 & 7.5 & 12.9 \\
\cline { 2 - 6 } & 3 & 31 & 33.3 & 33.3 & 46.2 \\
\cline { 2 - 6 } & 4 & 39 & 41.9 & 41.9 & 88.2 \\
\cline { 2 - 6 } & 5 & 11 & 11.8 & 11.8 & 100.0 \\
\cline { 2 - 6 } & Total & 93 & 100.0 & 100.0 & \\
\hline
\end{tabular}

Focusing on the seasonal and irregular nature of trade, and associated impact on the ability to forecast growth, Table 8 reflects on the respondents' level of agreement if it make it difficult to forecast growth. The majority of the respondents 39(42\%) agreed that the seasonal and irregular nature of trade make difficult to forecast growth in their businesses. The next high frequency was recorded for 31 (33\%) disagree with the statement.
Table 9. Lack of entrepreneurial skills is a challenge to growth

\begin{tabular}{|c|c|c|c|c|c|}
\hline \multicolumn{2}{|c|}{} & Frequency & Percent & Valid percent & Cumulative percent \\
\hline \multirow{4}{*}{ Valid } & 1 & 4 & 4.3 & 4.3 & 4.3 \\
\cline { 2 - 6 } & 2 & 4 & 4.3 & 4.3 & 8.6 \\
\cline { 2 - 6 } & 3 & 10 & 10.8 & 10.8 & 19.4 \\
\cline { 2 - 6 } & 4 & 37 & 39.8 & 39.8 & 59.1 \\
\cline { 2 - 6 } & 5 & 38 & 40.9 & 40.9 & 100.0 \\
\cline { 2 - 6 } & Total & 93 & 100.0 & 100.0 & \\
\hline
\end{tabular}

Table 9 on the lack of entrepreneurial skills, assessed respondents' level of agreement to how critical these factors were to the growth of incubatee's businesses. The two responses agree and strongly agree almost had the same frequency $37(40 \%)$ and $38(41 \%)$, respectively. The findings of this study also indicated that lack of entrepreneurial skills is a challenge to the growth of business incubatees. Entrepreneurial skills include creativity, innovation, risk-taking and ability to interpret successful entrepreneurial role models and identification of opportunities (Fatoki, 2012; Lose \& Tengeh, 2015). The results of this research paper are in consistence with literature.

Table 10. Managerial weakness is a challenge to growth

\begin{tabular}{|c|c|c|c|c|c|}
\hline \multicolumn{2}{|c|}{} & Frequency & Percent & Valid percent & Cumulative percent \\
\hline \multirow{4}{*}{ Valid } & 1 & 5 & 5.4 & 5.4 & 5.4 \\
\cline { 2 - 6 } & 2 & 23 & 24.7 & 24.7 & 30.1 \\
\cline { 2 - 6 } & 3 & 20 & 21.5 & 21.5 & 51.6 \\
\cline { 2 - 6 } & 4 & 34 & 36.6 & 36.6 & 88.2 \\
\cline { 2 - 6 } & 5 & 11 & 11.8 & 11.8 & 100.0 \\
\cline { 2 - 6 } & Total & 93 & 100.0 & 100.0 & \\
\hline
\end{tabular}

Table 10 shows that $5(5 \%)$ of the respondents said strongly disagree; 23 (25\%) replied disagree; 20 (22\%) said they were neutral; 34 (37\%) agreed and $11(12 \%)$ answered strongly agree. Data from the study revealed that most business incubatees experience managerial weaknesses and this hampers their growth. This is in line with Ihua (2009) who emphasized that lack of managerial skills culminates in too poor management of resources by the owner or managers (entrepreneurs) of small businesses which continue to fuel the challenges of business growth. These results are in line with works of Longenecker, Moore, Pettey and Palich (2006) who revealed that the lack of managerial skills limit small business survival and sustainability.

Table 11. Lack of access to external market is a challenge to growth

\begin{tabular}{|c|c|c|c|c|c|}
\hline \multicolumn{2}{|c|}{} & Frequency & Percent & Valid percent & Cumulative percent \\
\hline \multirow{4}{*}{ Valid } & 1 & 4 & 4.3 & 4.3 & 4.3 \\
\cline { 2 - 6 } & 2 & 9 & 9.7 & 9.7 & 14.0 \\
\cline { 2 - 6 } & 3 & 15 & 16.1 & 16.1 & 30.1 \\
\cline { 2 - 6 } & 4 & 44 & 47.3 & 47.3 & 77.4 \\
\cline { 2 - 6 } & 5 & 21 & 22.6 & 22.6 & 100.0 \\
\cline { 2 - 6 } & Total & 93 & 100.0 & 100.0 & \\
\hline
\end{tabular}


Table 11 dealt with how the lack of access to external market impacted on growth, required respondents to indicate the degree to which they agreed to a related statement. A total of $44(47 \%)$ of the incubatees agreed that lack of access to external market affect their business growth, while $21(23 \%)$ strongly agree that lack of access to external market was a challenge to growth. These results are in line with the results of Masutha and Rogerson (2014) who noted that business incubatees have only $7 \%$ access to the external (international) markets, whereas local markets accounted for 93\%. This shows that incubatees have limited chances of expanding their market internationally.

\section{Conclusion, limitation and scope for future research}

To sustain entrepreneurial activity that fosters economic growth, job creation and poverty reduction, businesses are obliged to grow or at least maintain long-term survival. For those on the incubation platform, the onus rests with the relevant stakeholders to identify and remove the obstacles to growth.
Focusing on the primary stakeholder, this paper investigated the critical factors that hinder the growth of incubatees in South Africa, in order to create awareness of these factors and to provide a platform for policy directives. The paper revealed that business incubatees are confronted with critical factors that hinder the growth of their businesses. These factors are not limited to: limited access to funding, lack of credit facility, inability to communicate effectively with incubation managers, inability to communicate effectively with incubation managers, competition, crime, the seasonal and irregular nature of trade, lack of entrepreneurial skills, lack of access to external market and lack of product selection and design. In spite of the contribution of this study, it has its limitations this opens up avenues for future research. Given that the present research was conducted in the Western Cape Province and Gauteng Province of South Africa, perhaps if data collection is expanded to include other areas in South Africa, the findings might be more insightful. In addition, it was going to be more robust if the study included both qualitative and quantitative methods.

\section{References}

1. Albort-Morant, G. \& Ribeiro-Soriano, D. (2016). A bibliometric analysis of international impact of business incubators, Journal of Business Research, 69 (5), pp. 1775-1779.

2. Asoba, S.N. \& Tengeh, R.K. (2016). Analysis of start-up challenges of African immigrant-owned businesses in selected craft markets in Cape Town, Environmental Economics, 7 (2), pp. 97-105.

3. Bergek, A. \& Norman, C. (2008). Incubator best practice: A framework, Technovation, 28 (1), pp. 20-28.

4. Buys, A.J. \& Mbewana, P.N. (2007). Key success factors for business incubation in South Africa: the Godisa case study, South African Journal of Science, 103 (9-10), pp. 356-358.

5. Berndt, A. \& Petzer, D. (2011). Marketing research. Cape Town: Pearson Education.

6. Bryman, A. \& Bell, E. (2011). Business research methods. $3^{\text {rd }}$ ed. New York: Oxford University Press.

7. Choto, P., Tengeh, R.K. \& Iwu, C.G. (2014). Daring to survive or to grow? The growth aspirations and challenges of survivalist entrepreneurs in South Africa, Environmental Economics, 5 (4), pp. 93-101.

8. Choto, P. (2015). The impact of business incubators on survivalist entrepreneurs in the Cape Metropolitan area. MTech Thesis. Cape Town. Cape Peninsula University of Technology.

9. Chirambo, F.M.C. (2014). An exploratory study on the performance of business incubators in South Africa. Masters Thesis. Johannesburg. University of the Witwatersrand.

10. Cullen, M., Calitz, A. \& Chandler, L. (2014). Business Incubation in the Eastern Cape: A Case Study, International Journal for Innovation Education and Research, 2 (5), pp. 76-89.

11. Clow, K.E. \& James, K.E. (2014). Essentials of marketing research: putting research into practice. California: Sage.

12. Coldwell, D. \& Herbst, F. (2004). Business research. Cape Town: Juta.

13. Dahlberg, L. \& Mccai G.C. (2010). Practical research and evaluation: a start-to-finish guide for practitioners. London: Sage.

14. Denscombe, M. (2007). The good research guide: for small-scale social research projects. $3^{\text {rd }}$ ed. New York: McGraw Hill.

15. Diedericks, R. (2015). Incubator services that small service organizations require from a university business incubator. Doctoral dissertation, North West. North-West University.

16. Du Plessis, P.J. \& Rousseau, G.G. (2007). Buyer behavior: understanding consumer psychology and marketing. Cape Town: Oxford University Press.

17. Dubihlela, J. \& Van Schaikwyk, P.J. (2014). Small business incubation and the entrepreneurial business environment in South Africa: a theoretical perspective, Mediterranean Journal of Social Sciences, 5 (23), pp. 264-269.

18. Dube, B., Roberts-Lombard, M. \& Van Tonder, E. (2015). Management Guidelines for Universal Quality Challenges across the Focus Group Research Process, The Journal of Applied Business Research, 31 (1), pp. 239-254.

19. Ekeledo, I. and Bewayo, E.D. (2009). Challenges and opportunities facing African entrepreneurs and their small firms, International Journal of Business Research, 9 (3), pp. 52-59.

20. Ihua, U.B. (2009). SMEs key failure-factors: A comparison between the United Kingdom and Nigeria, Journal of Social Science, 18 (3), pp. 199-207. 
21. Justino, M.V. \& Tengeh, R.K. (2016). Role of external environmental factors in the failure of small enterprises in Angola, Environmental Economics, 7 (2), pp. 86-96.

22. Kanchana, R.S., DivyA, J.V. \& Beegom, A.A. (2013). Challenges faced by new entrepreneurs, International journal of current research and academic review, pp. 2347-3215.

23. Kavhumbura, V.O. (2014). Beyond Godisa: critical success factors for business incubators in South Africa. Masters thesis. Johannesburg. University of the Witwatersrand.

24. Kent, R. (2007). Marketing research: approaches, methods and applications in Europe. London: Thomson Learning.

25. Keil, M.C.M.P. (2009). An investigation into the success factors amongst small businesses in Gauteng. Doctoral dissertation. University of Johannesburg.

26. Koech, B.C. (2011). A survey of the financial constraints hindering growth of SME's in Kenya: the case of Kamukunji district in Nairobi County. Masters of Business Administration, Dissertation. School of Business University of Nairobi.

27. Lose, T. \& Tengeh, R.K. (2015). The Sustainability and Challenges of Business Incubators in the Western Cape Province, South Africa, Sustainability, 7 (10), pp. 14344-14357.

28. Lose, T., Maziriri, E.T., Madinga, W. (2016). Assessing the Impact of Incubation Program to Small and Medium Enterprises Development in the Western Cape Province of South Africa, International Journal of Small Business and Entrepreneurship Research, 4 (4), pp. 16-29.

29. Lose, T. \& Tengeh, R.K. (2016). An evaluation of the effectiveness of business incubation programs: a user satisfaction approach, Investment Management and Financial Innovations, 13 (2), pp. 370-378.

30. Longenecker, J.G., Moore, C.W., Petty, J.W., Palich, L.E. \& McKinney, J.A. (2006). Ethical attitudes in small businesses and large corporations: Theory and empirical findings from a crackings study spanning three decades, Journal of Small Business Management, 44 (2), pp.167-183.

31. Masutha, M. \& Rogerson, C.M. (2014). Small enterprise development in South Africa: The role of business incubators. Bulletin of Geography, Socio-economic Series, 26 (26), pp. 141-155.

32. Mambula, C. (2002). Perceptions of SME Growth Constraints in Nigeria, Journal of Small Business Management, 40 (1), pp. 58-65.

33. Ntlamelle, T. (2015). The efficacy of SMME incubation as a strategy for enterprise development in South Africa. Masters Thesis. Johannesburg. University of the Witwatersrand.

34. Okpara, J.O. (2011). Factors constraining the growth and survival of SMEs in Nigeria: Implications for poverty alleviation, Management Research Review, 34 (2), pp. 156-171.

35. Pretorius, M. \& Shaw, G. (2004). Business plans in bank decision-making when financing new ventures in South Africa, South African Journal of Economic and Management Sciences, 7, pp. 221-241.

36. Pooe, D.R.I., MafiniI, C. \& Makhubele, D.T. (2015). Investigating Municipal Procurement Challenges in South Africa: A Qualitative Study, International Business \& Economics Research Journal, 14 (1), pp. 67-78.

37. Roets, C.R.Q. (2013). Black generation y students' attitudes towards the de-marketing of smoking and alcohol consumption. Unpublished master of commerce in Marketing Management dissertation. Vaal triangle. North West University.

38. SEDA. (2016). Incubation Centres. Available at: http://www.seda.org.za/MyBusiness/STP/Pages/AboutSTP.aspx. Accessed on 17/08/ 2016.

39. Sheldon, G.L. (2015). Off-field management of Western Province Super League a rugby clubs. Master of Technology: Unpublished Master's Thesis in Business Administration. Cape Town. Cape Peninsula University of Technology.

40. Shenura, S., Haile, A. \& Negash, E. (2016). Challenges Inhibiting the Flourishing of Entrepreneurial Competencies of MSE's in Jimma Zone, Ethiopia, International Journal of Scientific and Research Publications, 6 (2), pp. 137-145.

41. Tengeh, R.K. \& Choto, P. (2015). The relevance and challenges of business incubators that support survivalist entrepreneurs, Investment Management and Financial Innovations, 12 (2), pp. 150-161.

42. Vijayalakshmi, G. \& Sivapragasam, C. (2008). Research methods: tips and techniques. Chennai: MJP Publishers.

43. Wallace, J. (1999). Small Enterprise Development in Africa: Lessons from Success.

44. Olawale, F. \& Garwe, D. (2010). Obstacles to the growth of new SMEs in South Africa: A principal component analysis approach, African journal of Business management, 4 (5), pp. 729-738.

45. Walobwa, N.D., Ngugi, J.K. \& Chepkulei, B. (2013). Effect of the type of innovation on the growth of small and medium enterprises in Kenya: a case of garment enterprises in Jericho, Nairobi, European Journal of Management Sciences and Economics, 1 (2), pp. 49-57.

46. Worku, Z. (2015). Analysis of predictors of sustained growth and incubation of SMMEs in Gauteng Province, South Africa. Journal of Economics, 6 (2), pp. 250-259.

47. Willemse, J. (2010). The Forum SA. SME Failure Statistics. Available at: http://www.theforumsa.co.za/forums/showthread.php/7808-SME-Failure-Statistics. Accessed on 17/08/2016.

48. Yeboah, M.A. (2015). Determinants of SME Growth: An Empirical Perspective of SMEs in The Cape Coast Metropolis, Ghana, The journal of business in developing nations, 14 (1), pp. 2-31. 